\title{
Upside of Evidence by Public Prosecutor in The Case Corruption by Act No. 31 of 1999 jo. Act No. 20 of 2001 on Combating Crime of Corruption
}

\author{
Suwono ${ }^{1}$ and Jawade Hafidz ${ }^{2}$ \\ Abstract. Corruption is a criminal offense that is remarkable. Remarkable because \\ the mode used increasingly sophisticated, and as a result of corruption is very \\ detrimental to the people and the state. Corruptor often me-take advantage of \\ legal loopholes. Reverse authentication system implemented in the Act No. 31 of \\ 1999 jo. Act No. 20 of 2001 on Corruption Eradication easier for prosecutors to \\ prove that the defendant has committed the crime of corruption. In the system of \\ proof, the defendant has the obligation to prove that the defendant did not \\ commit corruption, and prosecutors also continue to prove that the defendant \\ engaged in corruption cases. \\ Keywords: Upside Evidence; Prosecution; Corruption.
}

\section{Introduction}

Corruption in Indonesia has penetrated into the entire line of people's lives, and even said to have entrenched in society. Widespread corruption, which is carried out systematically. Not only financial harm the country, but corruption also have violated the rights of social and economic, that are classified as extraordinary crime. In fact, a good number of cases, losses to the state and its modus operandi is increasing from year to year.

In addition to already entrenched in society, corruption has occurred in all areas of governance, whether executive, legislative, and judicial. Label corruption is not solely reserved for civil servants. Military, police, employees of state-owned companies / enterprises or members of national and provincial legislatures, or the officials and actors function judicial, or conglomerates and community members with specific tasks which are directly or indirectly related to the public interest, such as lawyers, public accountants, notaries and etc. ${ }^{3}$

Widespread corruption in the various joints of government has disrupted the wheels of government and bore huge losses to the national finance and economy. Seeing the losses incurred, then corruption can be categorized as regulatory offenses or offenses that preclude even robs the results of government efforts in the welfare of its people. ${ }^{4}$

Corruption is detrimental for the country, especially the land used as a state finance officials to enrich themselves, families and cronies. Not the least amount of public money they take and the rights of people who should be able to sit in the seat of government, was taken by the inappropriate and does not have all the inability, so that the countries that were destroyed. ${ }^{5}$

Combating corruption is not an easy task to do and may soon be resolved, because the government administration system that seemed not transparent, not accountable, the attitude is subject to the leadership, collusion and nepotism. The situation is further

\footnotetext{
${ }^{1}$ Student Masters (S-2) of Law Faculty of Law UNISSULA Semarang E-mail: suwonotoc@gmail.com

${ }^{2}$ Lecture of Faculty of Law UNISSULA Semarang,

3 Jeremy Pope 2003 Strategi Memberantas Korupsi Elemen Sistem Integritas Nasional Buku Panduan Transparency Interbational First Edition Yayasan Obor Indonesia Jakarta p. xxi.

${ }^{4}$ Ibid. p. 10.

${ }^{5}$ Jawade Hafidz Arsyad 2013 Korupsi Dalam Perspektif HAN (Hukum Administrasi Negara) First Edition Sinar Grafika Jakarta p. 9.
} 
compounded and nearly the decision when witnessed law enforcement officials from upstream to downstream involved in a web of corruption that should be used as a enemy of law enforcement or law enforcement target itself. ${ }^{6}$

Amendment of legal policy in the form of legislation regulating the eradication of corruption, and the latter is Act No. 20 of 2001 regarding the Second Amendment to Act No. 31 of 1999 on Corruption Eradication, at least the legal framework for enforcement laws to prevent and eradicate corruption.

By doing so, the prosecutors have sufficient guidance for drag corruptors to court over their actions were detrimental to the financial and economic state although it must also be recognized that for deciding cases, judges often have to hold new jurisprudencejurisprudence. Nor does it mean that with his force of this law, all the problems solved. There are still many aspects of corruption that needs to be regulated, because corruption may include other fields. However, the gap between the codification of law (ius constitutum) and deeds should be convicted (ius constituendum) must be bridged so that people can really feel the apparatus function of the judiciary and the legislative function. ${ }^{7}$

In the eradication of corruption, before the enactment of Act No. 31 of 1999 jo. Act No. 20 of 2001 is still usually use the verification system as set forth in the Code of Criminal Procedure, which turned out to be ineffective because the process takes a long, complicated, and difficult to predict the level of success as in proving corruption cases had been charged to the public prosecutor that the process must go through the examination in court. It clicking illustrate that the pattern of evidence that long failed to provide direction to optimize the handling of corruption cases.

The failure of the prosecutor to win a case of corruption due to the difficulty of the prosecutor to prove the defendant has committed the crime of corruption. The public prosecutor did not have the tools and the evidence sufficient to prove that the defendant actually committed the crime of corruption, or here prosecutor's difficult to prove that the defendant has harmed the state's finances and wealth result of corruption. ${ }^{8}$

In the criminal justice system, proof of whether or not the defendant acts as indicted play an important role because it is the most decisive in the imposition of criminal sanctions for actions against the guilt or innocence of a defendant.

Inverted authentication system is a system that put the burden of proof on the accused and the proof is only valid during the examination at the trial with the possibility to do additional examinations (special) if the examination in the trial in-ketemukan property belonging to the defendant allegedly derived from criminal acts of corruption but it has not been indicted. Even if the decision of the lawyer-justice has obtained permanent legal force, but it is known there is still a convict's property allegedly derived from criminal acts of corruption, the state can perform a civil suit against the convict or his heirs. In the system of proof of corruption is, a defendant must demonstrate that its wealth is not the result of corruption. If the defendant can prove that his wealth came not from corruption and judges based on existing evidence to justify the defendant shall be acquitted of all charges. If the opposite happens, the defendant was found guilty and sentenced.

\footnotetext{
${ }^{6}$ Jeremy Pope op.cit. p. 1.

${ }^{7}$ Indriyanto Seno Adji 2006 Korupsi Kebijakan Aparatur Negara dan Hukum Pidana First Edition Diadit Media Jakarta p. 272.

${ }^{8}$ Romli Atmasasmita 2004 Sekitar Masalah Korupsi Aspek Nasional dan Aspek Internasional Mandar Maju Bandung p. 55.
} 
From the description above introduction, the authors formulate the problem of: How can reverse authentication is done by the public prosecutor in proving the defendant guilty of corruption in the courts?

\section{Results and Discussion}

Legally-formal, understanding of corruption, should never give a clear definition of the purpose of corruption. But in Act No. 31 of 1999 on the Eradication of Corruption-an only gives an overview of the purpose of corruption was, namely in Article 2, which states that:

- Any person who unlawfully, committing enriched themselves or others a cooperative that can be detrimental to the state finance or economy of the state, shall be punished with imprisonment for life or imprisonment for a minimum 4 years and maximum 20 years and a fine of at least $200.000 .000,00$ (two hundred million rupiah) and at most $1,000,000,000.00$ (one billion rupiah);

- In this case of corruption, as referred to in paragraph (1) shall be done under certain circumstances, the death penalty may be dropped.

Article 3 states any person with the intention of enriching himself or another person or a corporation abusing power, opportunity or means available to him because of the position or positions that can be detrimental to the country's financial punishment shall be imprisonment for life or imprisonment of a minimum of 1 (one) years and a maximum of 20 (twenty) years and / or a fine of 50,000,000, - (fifty million rupiah) and at most Rp1,000,000,000, - (one billion rupiah).

In the handling of corruption, given that corruption is an extraordinary crime, so that the handling had to be through means exceptional. The prosecutor was given the task and authority of legislation to prove that the defendant engaged in the case indicted.

The prosecutor institution has the main task, namely to screen appropriate cases submitted to the court; prepare the necessary paperwork for instance make the indictment, proving in advance the trial and the prosecution and implement the court ruling. ${ }^{9}$

Besides listed in the Code of Criminal Procedure, duties and authority of the Prosecutor of the Republic of Indonesia in carrying out its duties and functions as subsystems or components of law enforcement criminal justice system Indonesia is listed in the Code of Criminal Procedure, Act No. 5 of 1991 jo. Act No. 16 of 2004 on the State Prosecutor of the Republic of Indonesia.

Act No. 16 of 2004 on the provisions of Article 1 point 1 and 2, of the formula, there are two authorized prosecutor is a prosecutor and as an executor. While the public prosecutor is authorized to prosecute and carry out the determination of the judge.

Prosecutor handling the case in the prosecution stage called the prosecutor. The public prosecutor who can carry out the determination of the judge. Thus, another prosecutor can not carry out the determination of the judge but still prosecutors can execute because he was the one prosecutors. Differences prosecutor and the public prosecutor is essentially the prosecutor on duty in case handling activities at the stage of prosecution, he still referred to the prosecutor. ${ }^{10}$

\footnotetext{
${ }^{9}$ Edi Setiadi dan Kristian 2017 Sistem Peradilan Pidana Terpadu dan Sistem Penegakan Hukum Di Indonesia First Edition Cetakan Kesatu Kencana Prenada Media Jakarta p. 114.

${ }^{10}$ Viswandro Maria Matilda dan Bayu Saputra 2015 Mengenal Profesi Penegak Hukum First Edition Pustaka Yustisia Yogyakarta p. 48.
} 
In Article 1 paragraph 1 of Act No. 16 of 2004, in-specify that: "The prosecutor is functional officers who are authorized by this Act to act as a public prosecutor and the executor of court decisions that have acquired legal force and other authorities by law". Furthermore, according to Article 1 paragraph 2 of Act No. 16 of 2004, states that: "The public prosecutor is a prosecutor who is authorized by this Act to re-do the prosecution and carry out the determination of the judge".

The public prosecutor was appointed the study and held a research for the content dossier, then make a research paper whether the case meets the requirements to be submitted / transferred to the court or sent to the State Attorney in the jurisdiction of the District Court will hear the case (Article 84 up to Article 86 of the Criminal Procedure Code) or handed over to other agencies, or was stopped prosecutions or make a research paper containing notes that the case was of public interest (Article 35 c of Act No. 16 Of 2004 jo. Elucidation of Article 77 of the Criminal Procedure Code). ${ }^{11}$

As we know that the nature of big corruption cases difficult for proof, which often ended with the acquittal of the defendant corruption judge actions. Government officials involved in corruption are often in a position to complicate the investigation that also make it difficult for investigators to obtain evidence. Likewise, major corruptions that have occurred in state institutions including the investigator and prosecutor agencies, also complicate the collection of evidence, thereby increasing the level of difficulty in determining the validity and proof strength values (probative). ${ }^{12}$

Evidentiary problems are strictly regulated in the Criminal Justice System Formal group (event), the Criminal Law (Act No. 8 of 1981). If we analyze the meaning of "the system" (law of evidence), according to Martiman Prodjohamidjojo, can be interpreted as a whole from the elements relating to the rules of evidence and relate to one another, as well as the interplay in whole or unanimity. ${ }^{13}$

According to Article 184 Criminal Procedure Code, various items of evidence in the Criminal Code is the testimony of witnesses, expert testimony, letters, instructions, and information-indictment ter. In corruption, proof is also based on the Criminal Code, but there are some exceptions, especially in the handling of corruption is given that corruption is an extraordinary crime, so that the handling had to be through means exceptional. One form of exclusion of these codes are establish verified system corruption.

In criminal cases are generally based on Act No. 8 of 1981 on the Code of Criminal Procedure. Likewise, corruption, also based on Act No. 8 of 1981, but there are some exceptions.

One form of exclusion of Act No. 8 of 1981 is proving system corruption. Verification system of corruption according to Act No. 20 of 2001 on the Amendment of Act No. 31 of 1999 on the eradiction of Corruption is a system of proof is limited and balanced, as confirmed in Article 37 of Act No. 20 2001, namely:

(1) The defendant has the right to prove that he is not me-do corruption;

(2) In the event that the defendant can prove that he was not guilty of corruption, then

\footnotetext{
${ }^{11}$ Marwan Effendy 2010 Pemberantasan Korupsi dan Good Governance Cetakan Pertama Timpani Publishing Jakarta p. 49- 50.

12 M. Akil Mochtar 2009 Pembalikan Beban Pembuktian Tindak Pidana Korupsi Sekretariat Jenderal and Kepaniteraan Mahkamah Konstitusi Jakarta p. 13.

13 Indriyanto Seno Adji 2006 Korupsi dan Pembalikan Beban Pembuktian Kantor Pengacara and Konsultan Hukum Prof.Oemar Seno Adji S.H. \& Rekan Jakarta p. 83.
} 
the evidence used by the court as a basis for stating that the charge was not proven. System burden of proof in the Act No. 31 of 1999 is not a reversal of the burden of proof / evidence upside down in total and absolute as it is outlined by General Explanation of this Act, namely: "In addition, this law also apply evidentiary upside is limited or balanced, the defendant has the right to prove that he was not guilty of corruption and is required to provide information about the entire possessions and property of husbands and wives, children and property of any person or corporation who allegedly has links with cases concerned, and the public prosecutor still be obliged to prove the charges.

Elucidation of Article 37 states that: "This provision is a deviation from the provisions of the Code of Criminal Procedure which specifies that prosecutors are required to prove the crime, not the defendant. According to this provision, the defendant can back to prove that he is not guilty of corruption. If the accused can prove it does not mean he is not guilty of corruption, because the public prosecutor is still obliged to prove the charges. The provisions of this article constitute inverted ter-limits, because the prosecution is still required to prove the charges".

This provision does not negatively verification system adopted according law (negatief wettelijk). The defendant can prove no-involvement in committing corruption, but the evidence was not able to guarantee no-involvement into suspected corruption was because the prosecution is still obliged to prove the charges. ${ }^{14}$

System reversal of the burden of proof (general familiar with the system of proof) or reserval burden of proof (omkering van het bewijlast) is a new pattern that was adopted from the Anglo-Saxon legal system, given a bribe as an act of corruption have the highest level of indication, but very limitedly success. Repression of bribery with a pattern of evidence that long failed to provide direction-ization optimal handling.

The reversal of the burden of proof in the Law on Corruption applied at the level of investigation in court, by sticking to the philosophy of the nation of Indonesia, Pancasila that promote human rights. ${ }^{15}$

With regard to the system of proof, any civil servant or state officials based on the evidence starters backs possess wealth disproportionate to income or resource, then he is obliged to prove the validity of the wealth that it generates. Process outlined in Article 37A, Article 38A and Article 38B of Act No. 20 of 2001.

Implementation of the system of proof that is "limited" and "balanced" against certain actions and also concerning confiscation of proceeds of corruption as a manifestation of the determination or the good will of the organizers of the state in combating corruption and trying to restore the loss of all state due to corruption. In this regard, the defendant is entitled to prove that he was not guilty of corruption, and the public prosecutor still prove the corruption. ${ }^{16}$

\section{Closing}

\subsection{Conclusion}

Act No. 31 of 1999 jo. Act No. 20 of 2001 on Corruption Eradication in the legal framework

\footnotetext{
14 IGM. Nurdjana 2005 Korupsi Dalam Praktik Bisnis Pemberdayaan Penegakan Hukum Program Aksi dan Strategi Penanggulangan Masalah Korupsi First Edition Gramedia Pustaka Utama Jakarta p. 63.

15 A. Djoko Sumaryanto 2009 Pembalikan Beban Pembuktian Tindak Pidana Korupsi Dalam Rangka Pengembalian Kerugian Keuangan Negara Prestasi Pustaka Publisher Jakarta p. 11 and 12.

${ }^{16}$ Ibid.
} 
for law enforcement to combat and eradicate corruption. Corruption is an extraordinary crime, so that the handling had to be through means exceptional. The prosecutor was given the task and authority of legislation to prove that the defendant was involved in corruption cases that are indictment. Act No. 31 of 1999 jo. Act No. 20 of 2001 to implement the system of proof easier for prosecutors to prove the accused involved in corruption cases. Act No. 31 of 1999 jo. Act No. 20 of 2001 introduced a system of proof is limited and balanced,

Application of inverted authentication system that is limited and balanced against certain actions and also concerning confiscation of proceeds of corruption as a manifestation of the determination or the good will of the organizers of the state in combating corruption and trying to restore the country's financial rugian all due to corruption. In this regard, the defendant is entitled to prove that he was not guilty of corruption, and the public prosecutor still prove the corruption.

\subsection{Suggestion}

Of proof as regulated in Act No. 31 of 1999 jo. Act No. 20 of 2001 may also apply to offenses difficult in evidence. Prosecutors need to be given the authority to implement a reverse authentication if the cases handled by the prosecutor's difficult to prove.

\section{Bibliography}

[1] Djoko Sumaryanto 2009 Pembalikan Beban Pembuktian Tindak Pidana Korupsi Dalam Rangka Pengembalian Kerugian Keuangan Negara Prestasi Pustaka Publisher Jakarta.

[2] Edi Setiadi and Kristian 2017 Sistem Peradilan Pidana Terpadu and Sistem Penegakan Hukum Di Indonesia First Edition Kencana Prenada Media Jakarta.

[3] IGM. Nurdjana 2005 Korupsi Dalam Praktik Bisnis Pemberdayaan Penegakan Hukum Program Aksi and Strategi Penanggulangan Masalah Korupsi First Edition Gramedia Pustaka Utama Jakarta.

[4] Indriyanto Seno Adji 2006 Korupsi and Pembalikan Beban Pembuktian Kantor Pengacara and Konsultan Hukum Prof.Oemar Seno Adji S.H. \& Rekan Jakarta.

[5] ---------- 2006 Korupsi Kebijakan Aparatur Negara and Hukum Pidana First Edition Diadit Media Jakarta.

[6] Jawade Hafidz Arsyad 2013 Korupsi Dalam Perspektif HAN (Hukum Administrasi Negara) First Edition Sinar Grafika Jakarta.

[7] Jeremy Pope 2003 Strategi Memberantas Korupsi Elemen Sistem Integritas Nasional Buku Panduan Transparency Interbational 2002 First Edition Yayasan Obor Indonesia Jakarta.

[8] M. Akil Mochtar 2009 Pembalikan Beban Pembuktian Tindak Pidana Korupsi Sekretariat Jenderal and Kepaniteraan Mahkamah Konstitusi Jakarta.

[9] Marwan Effendy 2010 Pemberantasan Korupsi and Good Governance First Edition Timpani Publishing Jakarta.

[10] Romli Atmasasmita 2004 Sekitar Masalah Korupsi Aspek Nasional and Aspek Internasional Mandar Maju Bandung.

[11] Viswandro Maria Matilda and Bayu Saputra 2015 Mengenal Profesi Penegak Hukum First Edition Pustaka Yustisia Yogyakarta. 